\title{
Identifying Requirements of a Self-care System on Smartphones for Preventing Coronavirus Disease 2019 (COVID-19)
}

\author{
Hamidreza Saeidnia $^{1}$ (D), Zahra Mohammadzadeh ${ }^{2}$ (D) Mohammadreza Saeidnia $^{3}$ (D), \\ Amir Mahmoodzadeh ${ }^{4}$ (D) Neda Ghorbani ${ }^{5}$ (D) Mohammad Hasanzadeh $^{6 *}$ (D)
}

1. Department of Information Management, Tarbiat Modares University, Tehran, Iran

2. Department of Health Information Technology, Urmia University of Medical Sciences, Urmia, Iran

3. Department of Hematology, Shiraz University of Medical Sciences, Shiraz, Iran

4. Department of Clinical Biochemistry, Medical Biology Research Center, Health Technology Institute, Kermanshah University of Medical Sciences, Kermanshah, Iran

5. Department of Cellular \& Molecular, Qom Branch, Islamic Azad University, Qom, Iran

6. Department of Knowledge and Information Sciences, Tarbiat Modares University, Tehran, Iran

\section{ABSTRACT}

Background: Smartphone applications play a pivotal role in management, providing care and preventing infectious diseases. It also has the potential impact on supportive and self-care. This study aimed to identify the requirements for a smartphones self-care system to prevent corona-virus (COVID-19).

Materials \& Methods: This was a descriptive study performed in two main stages in 2020 . At the first stage, to recognize the requirements for a smartphones self-care system, similar articles were searched and identified. In the second stage, the identified requirements were validated through a researcher-made questionnaire. The sample size of the study consisted of infectious diseases specialists of Urmia University of Medical Sciences. The collected data was analyzed using descriptive statistics (mean and frequency).

Results: Requirements of the self-care system were identified in four areas: "demographic data, clinical requirements, selfcare strategies, and technical characteristics". Also, according to the research community, 5 data elements for demographic data, 11 data elements for clinical requirements, 5 data elements for self-care strategies, and 11 data elements for technical characteristics were selected.

Conclusion: Applying the requirements and suggested strategies in the present study can improve self-care skills to prevent corona-virus, symptoms management, motivate and reduce stress, increase personal hygiene and communication with health care providers.

Keywords: Self-care, Smart phone, Corona-virus (COVID-19)

Received: 2020/04/13;

Accepted: 2020/05/9;

Published Online: 2020/06/18

\begin{tabular}{cl} 
Corresponding Information: & $\begin{array}{l}\text { Mohammad Hasanzadeh, Professor Knowledge and Information Science, Tarbiat Modares University, Tehran, Iran. } \\
\text { Email: hasanzadeh @modares.ac.ir }\end{array}$ \\
\hline cc) (1) (5) Copyright ( 9 2020, This is an original open-access article distributed under the terms of the Creative Commons Attribution-noncommercial 4.0 International License which \\
permits copy and redistribution of the material just in noncommercial usages with proper citation.
\end{tabular}

Use your device to scan and read the article online

Saeidnia H, Mohammadzadeh Z, Saeidnia M, Mahmoodzadeh A, Ghorbani N, Hasanzadeh M. Identifying Requirements of a Self-care System on Smartphones for Preventing Coronavirus Disease 2019 (COVID-19). Iran J Med Microbiol. 2020; 14 (3) :241-251

Download citation: BibTeX | RIS | EndNote | Medlars | ProCite | Reference Manager | RefWorks
Send citation to:
Mendeley
2 Zotero
Hi RefWorks 


\section{Introduction}

Self-care is a practice in which people use the knowledge, their skill and ability as a resource to maintain and improve their health (1). Self-care is a laborious process that requires time and energy to perform the action. Implementation of this action depends on the internal (cognitive, physical, emotional and behavioral) and external (environment and society) capacities $(2,3)$. Self-care is one of the emerging operational strategies for the management and prevention of communicable infectious diseases. According to research, it results in increased energy and positive emotions, reducing stress, physical health feeling, increasing the self-confidence and enthusiasm and consequently, could improve the level of health of the community (4-7). According to the findings of similar research greater awareness of communicable diseases leads to better self-care $(8,9)$. Several articles in different countries have focused on the use of smartphones self-care software for the management of communicable infectious diseases $(10,11)$. Self-care is a voluntary activity that performs to provide, maintain and promote a healthy community (12). Therefore, Self-care includes activities that are applicable by each person (13) and could cause continuous assurance and long-term follow up of self-care activities (14).

Given the prevalence of corona-virus disease (COVID19) as a chronic disease and the importance of self-care in its prevention, providing self-care services can be an important achievement for the community and also given the widespread use of smartphones software and the low-cost of this technology, the use of smartphones self-care system is increasing in this area (15).

In addition to save time and expenses, it has an important role in managing and providing care for the prevention of corona-virus (COVID-19). In recent years development of smartphones software has led to the application of this software in a variety of health areas (16). Using this software has been a considerable help in management and prevention of chronic and communicable diseases in developed countries $(17,18)$.

Due to the lack of self-care software for the management and prevention of infectious diseases and lack of self-care software to prevent corona-virus disease (COVID-19) in Iran it is important to address this issue.

The purpose of this study was to identify the requirements for a smartphones self-care system to prevent corona-virus (COVID-19).

\section{Materials and Methods}

\section{Search strategy and study selection}

This descriptive study was conducted in two stages in the year 2020. The first stage of the study focused on identifying requirements of smartphones self-care system for coronavirus disease 2019 (COVID-19). The keywords Mobile, Self-care, Mobile health, Prevention Requirements, Minimum data set Self-Management Strategies, Smart Phone, corona-virus disease 2019 (COVID-19) and Acute disease were searched using AND operators in databases of PubMed, Scopus, the web of Science, science direct, Google Scholar and ProQuest. Review and original articles with self-care, corona-virus and corona-virus (COVID-19) topics published between 2001 and 2020 were checked. According to the mentioned criteria, we tried to gather as many articles as possible. A total of 246 articles were identified of which 195 were eliminated due to lack of inclusion criteria, being repeated or overlapped. Finally, 30 articles were selected $(15,16,18-45)$.

In the second stage, using obtained data while checking similar articles, a questionnaire was designed for validation and choosing the requirements for designing a smartphones self-care system to prevent Corona-virus infection. The questionnaire included 4 parts and 56 questions (Demographic data; 8 questions, Clinical requirements; 12 questions, Selfcare strategy and Technical characteristics; 12 questions) and it was designed based on five degrees Likert scale (from totally agree to completely disagree). The reliability of the questionnaire was calculated as 0.85 by Cronbach's alpha coefficient. The software's validity was also verified by infectious diseases specialists and health information management professors. The current research sample size has consisted of infectious diseases specialists, experienced nurses in patient education who were occupied in Urmia University of Medical Sciences that due to sample size limitation, the sampling process was not performed and the whole of the individuals were included in the study (22 individuals). Inclusion criteria were personal satisfaction, volunteering and completing all the questions in the questionnaire, and answering the questionnaire incompletely or incomplete answers were considered as cases of removing people from the study. The questionnaire was distributed between individuals and 20 questionnaires were collected after fulfillment. At this stage, the questionnaire's choices were scored from 1 to 5 (Totally agree: 5, I agree: 4, I don't think: 3, I disagree: 2 , and I completely disagree: 1 ). Then, each of the identified data elements and attributes were considered to be significant only if the infectious disease specialists had achieved at least a mean of 2.5 or more. Finally, the mean values given to each data element were calculated and the related descriptive tables were drawn. Data was analyzed using SPSS software version 22 (SPSS Inc., Chicago, III., USA).

\section{Results}


Based on the findings of the first stage of the study, the requirements for a smartphones self-care system for the prevention of corona-virus (COVID-19) were determined in the area of "demographic data requirements, clinical requirements, self-care strategies, and technical capabilities." According to the findings of the first step, 13 data elements for demographical requirements, 9 elements for clinical requirements, 8 technical characteristic requirements and 8 elements of the system self-care strategies were identified.
Based on the findings of the second stage of the investigation, from the data elements and characteristics identified in the first stage, 5 data elements for demographic requirements, 11 elements for clinical requirements, 5 elements for self-care strategies requirements and 11 elements for technical characteristics were selected.

The mean scores assigned by the infectious disease specialists to the identified requirements and selected items for each of the 4 parts (demographic, clinical information, self-care strategies, and technical characteristics) are presented in Table 1.

Table 1. Requirements for self-management system and average scores assigned by specialists

\begin{tabular}{|c|c|c|c|c|c|c|c|}
\hline $\begin{array}{l}\text { Demographic } \\
\text { data }\end{array}$ & Mean & Self-care strategy & Mean & $\begin{array}{l}\text { Clinical } \\
\text { requirements }\end{array}$ & Mean & $\begin{array}{c}\text { Technical } \\
\text { characteristics }\end{array}$ & Mean \\
\hline Age & 4.5 & $\begin{array}{l}\text { Motivate Yourself } \\
\text { (Thinking Positive) }\end{array}$ & 4.5 & $\begin{array}{l}\text { Dry and frequent } \\
\text { coughing }\end{array}$ & 5 & $\begin{array}{l}\text { Communication with } \\
\text { health units (remote } \\
\text { monitoring) }\end{array}$ & 5 \\
\hline Gender & 4.6 & Personal hygiene & 4.4 & $\begin{array}{l}\text { difficulty } \\
\text { breathing }\end{array}$ & 5 & Educational messages & 5 \\
\hline Location & 4.3 & Exercise & 4.2 & Ague & 5 & Contact with doctor & 5 \\
\hline Tel. number & 4.1 & Healthy diet & 4.1 & Sore throat & 4.9 & $\begin{array}{l}\text { Get news from valid } \\
\text { sources }\end{array}$ & 5 \\
\hline BMI & 3.8 & $\begin{array}{l}\text { General } \\
\text { recommendations }\end{array}$ & 3.9 & runny nose & 4.8 & Diet reminder & 4.5 \\
\hline- & - & - & - & $\begin{array}{l}\text { Tiredness and } \\
\text { weakness }\end{array}$ & 4.5 & Exercise reminder & 4.5 \\
\hline- & - & - & - & joint's pain & 4.2 & Motivational message & 4.5 \\
\hline- & - & - & - & Diarrhea & 4.1 & Text messaging & 4.4 \\
\hline- & - & - & - & Nocturnal sweat & 3.8 & Security Requirements & 4.3 \\
\hline- & - & - & - & Pneumonia & 3.8 & online & 4.2 \\
\hline- & - & - & - & Weight Loss & 3.7 & User-friendly & 4.1 \\
\hline
\end{tabular}

\section{Discussion}

Based on obtained results from the first stage of the present study, four demographic areas (with 5 data elements), Clinical requirements (with 11 data elements), Self-care strategies (with 5 data elements), Technical characteristics (with 11 data elements) were identified to design a smartphones software system to prevent corona-virus disease (COVID-19).

According to the infectious diseases specialists, 8 data elements were selected in the present study for the demographic area that was consistent with the results of Nematollahi et al.

They concluded that in designing and operating a comprehensive information management system for chronic and acute diseases the mechanism of enrollment of their full demographic information should be considered (46). A total of 11 data elements were also selected according to the infectious diseases specialists in the clinical field, which was in agreement with the result of the study by Jank JG et al. They concluded that the most common clinical symptoms of corona-virus (COVID-19) patients are fatigue, cough, fever, and digestive symptoms $(20,21)$. In the self-care strategies context, 5 data elements were selected according to the specialists that were consistent with the research by Fernandez et al. They supported the children's self-care and their families suffering from a contagious infectious disease that self-care strategies have been achieved included evaluations, counseling, care and accompaniment (47). Similar researches emphasizing on self-care strategies for acute and chronic conditions have highlighted the importance of improving the lifestyle of self-care programs, which could help to ameliorate their health status and increase their motivation and ability to participate in treatment plans $(48,49)$. The 
technical characteristics area was completed with 11 data elements selected by infectious disease specialists. In a similar study, Henry and Moore illustrated that the smartphones self-care could be fruitful in this context through present punctual reminders and people participation in related activities (50).

\section{Conclusion}

The study was conducted to identify the requirements of a mobile-based self-care system to prevent COVID-19. The results of the research indicated that the data elements of communication with health and medical units (remote monitoring), educational messages, communication with the doctor and receiving news from reputable sources are among the technical requirements with a very high range and an average of 5 . These have drawn the research community's attention to the importance of technical requirements which could be an important requirement to prevent COVID-19. Dry and frequent coughing, shortness of breath, fever and chills were other very important data elements with a very high spectrum and an average of 5 among the important and significant clinical requirements of the research community. It should be noted that the weight loss element with an average of 3.7 of the set of clinical requirements elements had the lowest average and the rest of the data elements of all identified requirements had an average above 3.7 , which shows the high importance of each of these data elements.

Applying the requirements and suggested strategies in the present study can improve self-care skills to prevent corona-virus, symptoms management, motivate and reduce stress, increase personal hygiene and communication with health care providers.

Suggestions: It is recommended to perform future investigations to develop and evaluate self-care system to prevent corona-virus (COVID-19).

\section{Acknowledgment}

The authors would like to thank all the professors and staff of the Virology Research Center of Masih Daneshvari Hospital and Urmia University of Medical Sciences who assisted us in this study.

\section{Conflict of Interest}

Authors declared no conflict of interests. 


$$
\begin{aligned}
& \text { مجله ميكروبشناسى يزشكى ايران }
\end{aligned}
$$

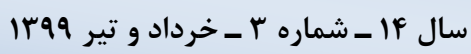

$$
\begin{aligned}
& \text { Journal homepage: www.ijmm.ir }
\end{aligned}
$$

شناسايى الزامات سامانه خود مراقبتى مبتنى بر كوشى همر اه هوشمند براى بِيشكيرى از ابتلا به ويروس كرونا (كوويد-19)

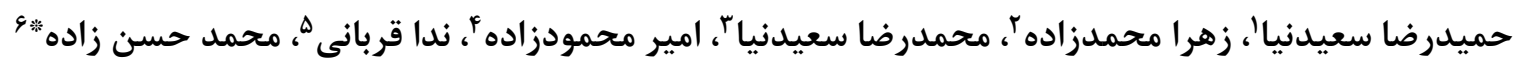

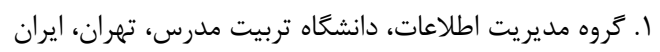

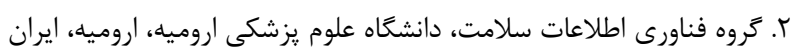

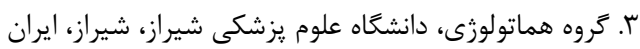

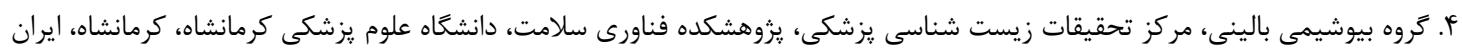

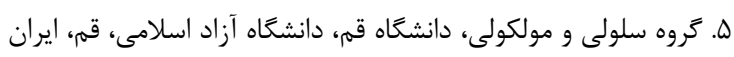

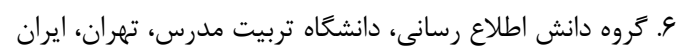

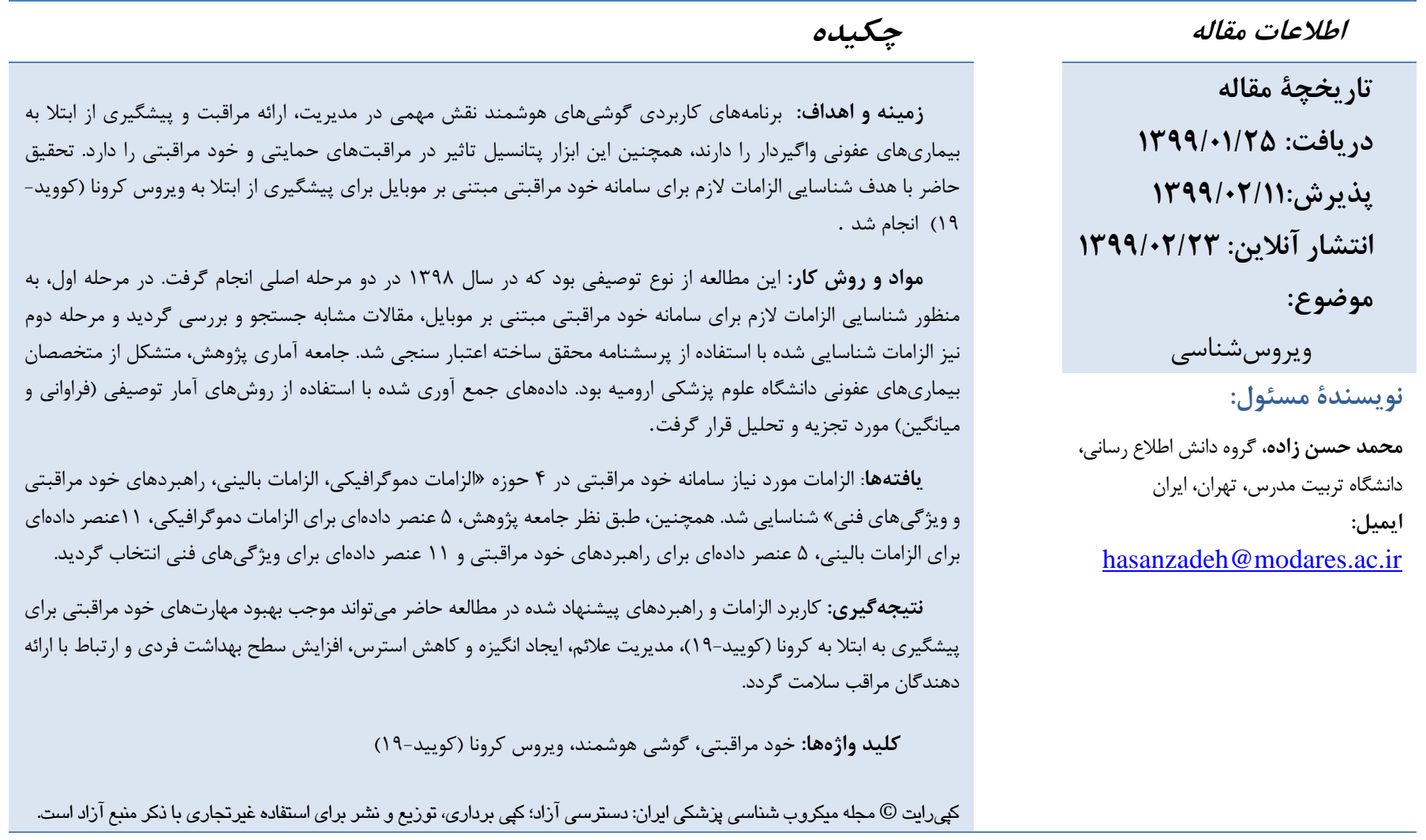

مقلدمه

جامعه) بستخى دارد (با، ץ). خود مراقبتى يكى از راهبردهاى

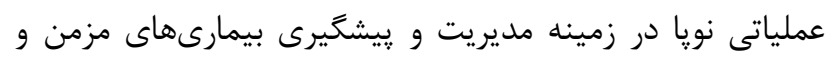

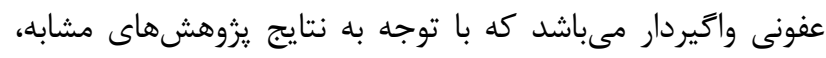

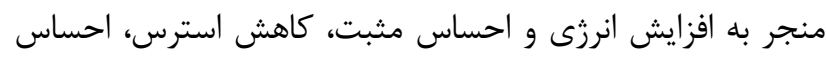

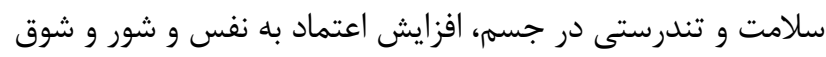

خود مراقبتى عملى است كه در آن، هر فردى از دانش، مهارت،

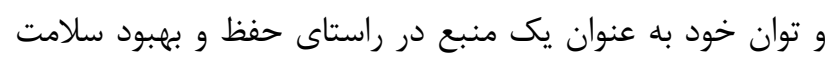

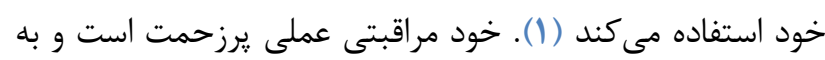

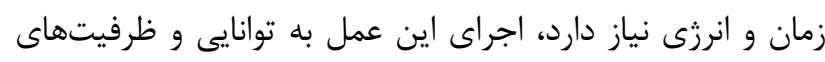

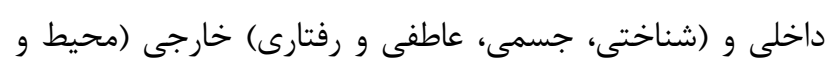


Mobile, Self-care, Mobile health, Prevention Requirements, Minimum data set Self-Management Strategies, Smart Phone, corona virus disease 2019 (COVID-19), Acute disease.

$$
\text { به صورت تركيبى در منابع اطلاعاتى }
$$

،scopus،, google scholar, ProQuest web of science مورد جستجو قرار زرفت. سعى شد PubMed gscience direct

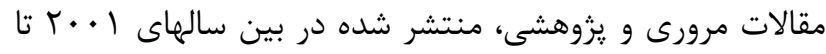
• • · r كه به موضوع خود مراقبتى، ويروس كرونا و ويروس كرونا

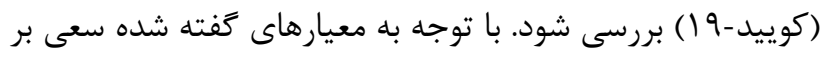
آن شد كه تا جايى كه امكان دارد اكثر مقالات گردآورى شود. جستجوى مقالات تا جايى ادامه پيدا كرد كه مقالات تكرارى شد

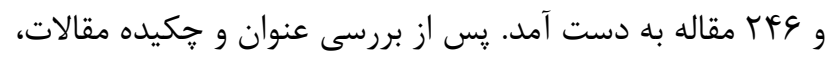

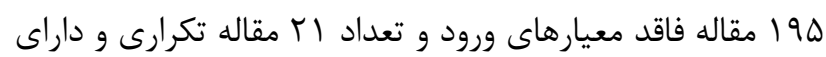
هميوشانى بودند حذف كه در نهايت • r مقاله انتخاب و به صورت

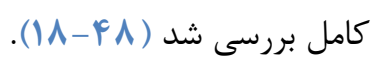

در مرحله دوم، با استفاده از اطلاعات به دست آمده از بررسى مقالات مشابه، يرسشنامهاى جهت اعتبار سنجى و انتخاب الزامات مورد نياز جهت طراحى سامانه خود مراقبتى مبتنى بر موبايل براى

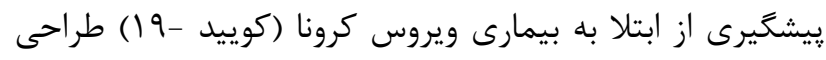

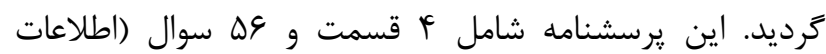

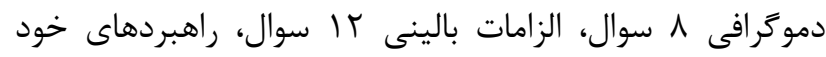

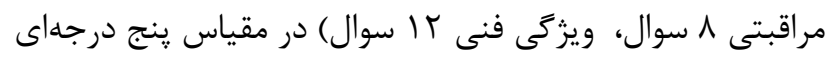

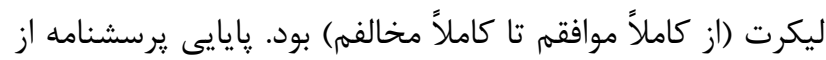
طريق محاسبه الفاى كرونباخ ND|• محاسبه شد. روايى ابزار نيز توسط متخصصان بيماريهاى عفونى و اساتيد رشته مديريت اطلاعات سلامت مورد سنجش و تاييد قرار گرفت. جامعه آمارى يزوهش حاضر عبارت از متخصصان بيماريهاى عفونى و يرستاران

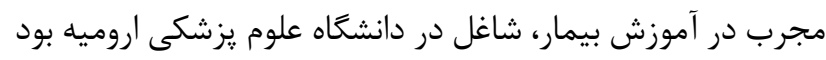
كه به دليل محدوديت افراد جامعه، نمونه گيرى انجام نشد و تمام افراد جامعه وارد مطالعه شدند (rT نفر). يرسشنامه به صورت

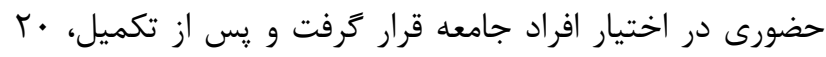
يرسشنامه جمع آورى گرديد. معيار ورود جامعه آمارى براى ترى تكميل يرسشنامه شامل: رضايت شخصى، داوطلبانه بودن و تكميل تمامى

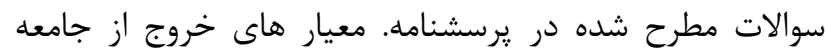
آمارى شامل ناقص ير كردن يرسشنامه. در اين مرحله گزينههاى يرسشنامه از 1 تا ه متياز دهى شد

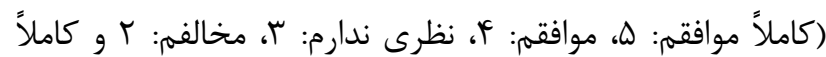

و ارتقا سطح سلامت افراد جامعه مى يافتههاى يزوهشهاى مشابه، آكاهى بيشتر در مورد بيمارىهاى

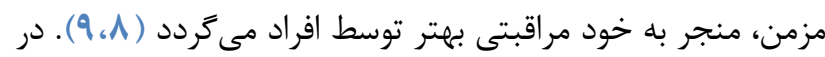

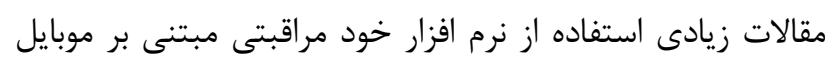
براى مديريت بيمارىهاى مزمن و عفونى در كشورهاى مختلف، مورد

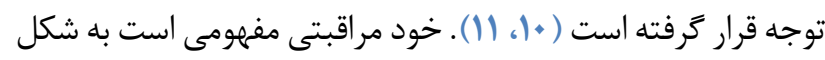
داوطلبانه و فعاليتى است كه فرد براى تأمين، حفظ و ارتقاى سلامت خود انجام مىدهد ( (I)). بنابراين، خود مراقبتى فعاليتهايى را در بر مى گيرد كه توسط خود شخص قابل اجرا مىباشد ( (I) و موجب

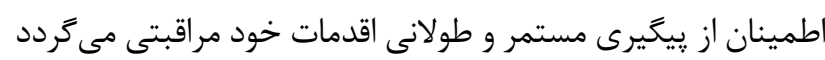

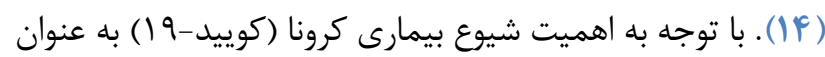

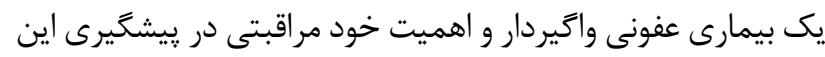
بيمارى، ارائه خدمات مبتنى بر خود مراقبتى مى تواند دستاوردى

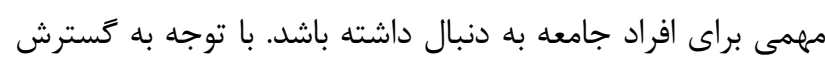

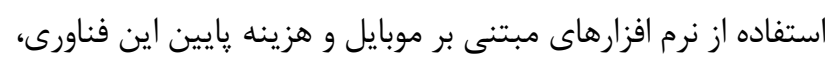

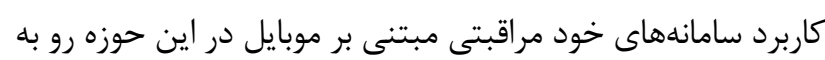
افزايش است (ه|(1) استفاده از اين سامانه مىتواند علاوه بر صرفه

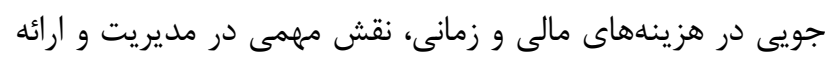

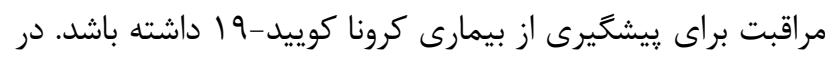

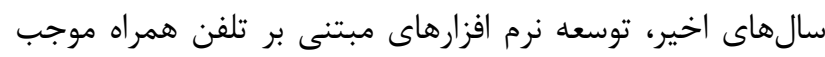

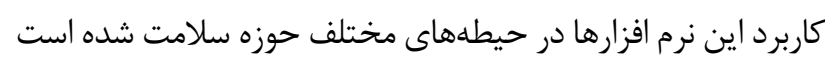

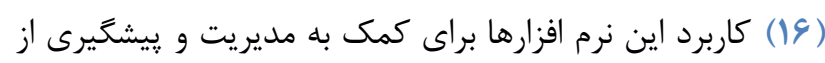
بيمارىهاى مزمن و عفونى واخيردار در كشورهاى توسعه يافته قابل برمايل توجه مىباشد (V) I 1) ). با اين حال، با توجه به عدم استفاده نرم

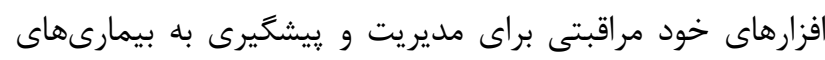

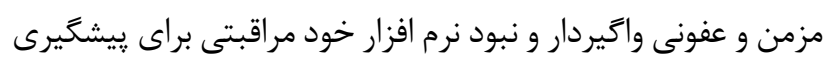

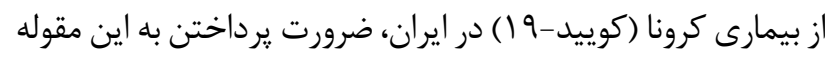

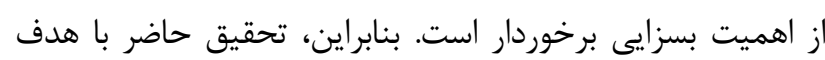

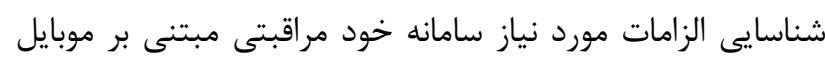
براى بيشخيرى از مبتلا شدن به بيمارى كرونا (كوييد-9 1) انجام

\section{روش يزوهش}

اين يثوهش از نوع توصيفى بود كه در دو مرحله در سال 19 ז انجام گرفت. در مرحله اول مطالعه جهت شناسايى الزامات سامانه خود مراقبتى براى ڤيشگيرى از ابتلا به بيمارى كرونا

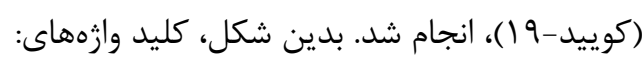


براى الزامات دمو گرافيكى، 9 عنصر براى الزامات بالينى، 1 عنصر

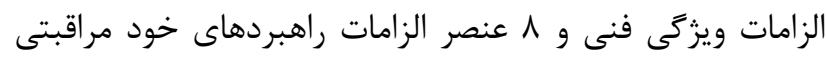
سامانه مذكور شناسايى شد.

بر اساس يافتههاى مرحله دوم يزوهش، از بين عناصر داداى

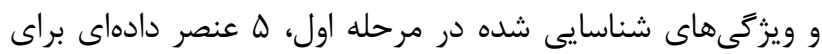

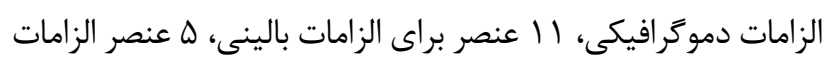

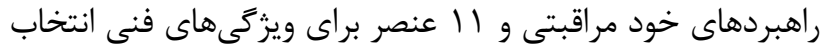
كرديد. ميانگين نمرات اختصاص داده شده توسط متخصصان بيمارهاى عفونى به الزامات شناسايى شده و آيتمهاى انتخاب شده براى هر F قسمت (اطلاعات دموكرافى، بالينى، راهبردهاى خود مراقبتى و ويزگى هاى فنى) در جدول آ آمده است.
مخالفم: () سيس هر يك از عناصر دادهاى و ويزَّى هاى شناسايى شده تنها در صورتى به عنوان ويزگى مهرم در نظر كرفته شد كه

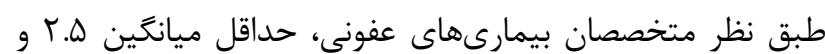
بيشتر را كسب كرده باشد. در نهايت، ميانكَين ارزشهاى دادئ داده شده به هر عنصر اطلاعاتى محاسبه و جداول توصيفى مربوط به آن رسم

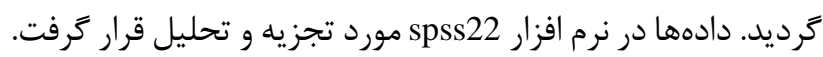

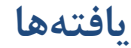

بر اساس يافتههاى مرحله اول يزوهش، الزامات مورد نياز

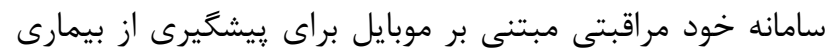

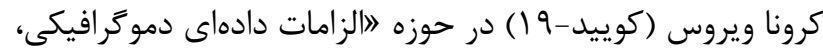

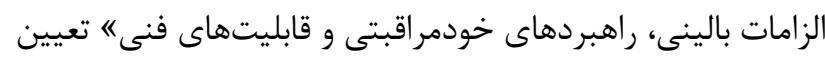

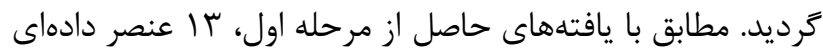

\section{نمودار ا. الزامات مورد نياز سامانه خود مديريتى و ميانگين نمرات اختصاص داده شده توسط متخصصان}

\begin{tabular}{|c|c|c|c|}
\hline اطلاعات دموكر افى & ميانكَين & راهبردهاى خودمراقبتى & ميانَين \\
\hline 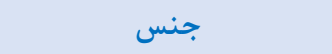 & f/9 & انخَيزه دادن به خود (مثبت فكر كردن) & $F / \Delta$ \\
\hline سن & $F / d$ & بهداشت فردى & $f / c$ \\
\hline محل زندگى & $f / r$ & ورزش كردن & $f / T$ \\
\hline شماره تماس & $f / 1$ & تغذيه سالم & $F / 1$ \\
\hline 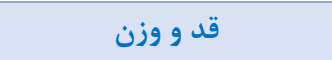 & $r / \Lambda$ & توصيdهاى عمومى & $r / 9$ \\
\hline 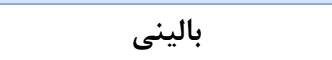 & 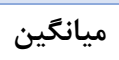 & ويثزى فنى & 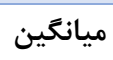 \\
\hline سرفه كردن خشك و مكرر & $\Delta$ & ارتباط با واحدهاى بهداشتى و درمانى (يايش از راه دور) & $\Delta$ \\
\hline تنغى نفس & $\Delta$ & 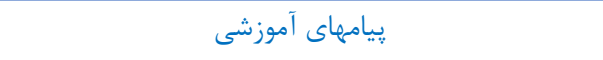 & $\Delta$ \\
\hline 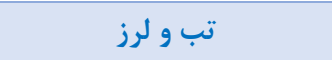 & $\Delta$ & 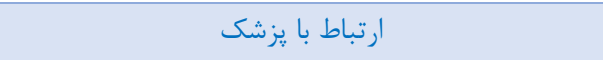 & $\Delta$ \\
\hline 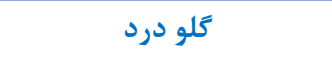 & $4 / 9$ & دريافت اخبار از منابع معتبر & $\Delta$ \\
\hline آب ريزش بينى & $\boldsymbol{F} / \mathrm{A}$ & يادآورى رزيم غذايى & $F / Q$ \\
\hline خستخى و بى حالى & $F / d$ & يادآورى ورزش & $F / d$ \\
\hline درد مفاصل & $f / T$ & 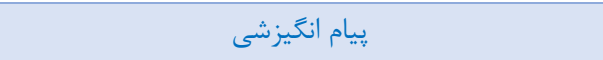 & $F / \Delta$ \\
\hline 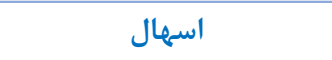 & $F / 1$ & 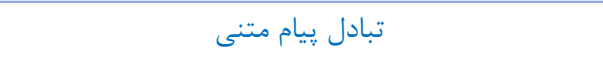 & $\boldsymbol{F} / \boldsymbol{F}$ \\
\hline تعريق شبانه & $\mathrm{r} / \mathrm{\Lambda}$ & الزامات امنيتى & $p / \mu$ \\
\hline ذات الريه & $r / 1$ & تحت وب بودن & $r / T$ \\
\hline 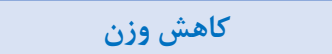 & $r / V$ & كاربر گِند بودن & $F / 1$ \\
\hline
\end{tabular}

\section{بحث}

داده اى) جهت طراحى سامانه خود مراقبتى مبتنى بر موبايل براى

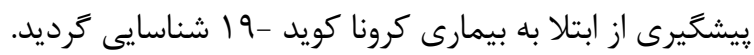
بر اساس تحقيق حاضر، \ عنصر دادهاى طبق نظر متخصصان

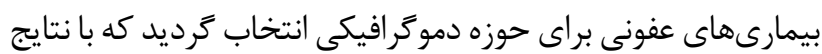

بر اساس يافتههاى مرحله اول يزوهش حاضر، أ حوزه

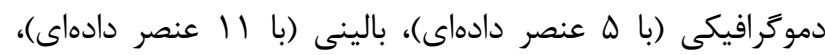

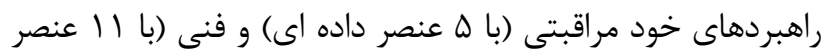


دهنده اهميت بالاى توجه به الزامات فنى است و مىتواند يك الزام

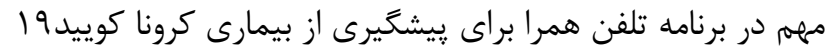

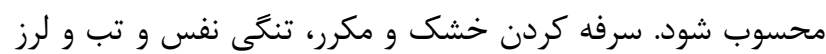

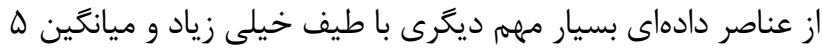

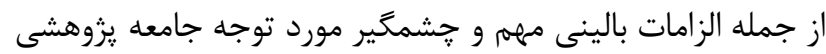
بود كه توجه به اين عناصر بسيار ضرورى است. لازم به ذكر است است كه

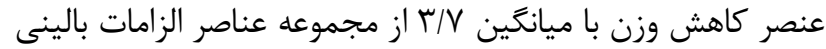
داراى كمترين ميانگين بوده و بقيه عناصر دادهاى از همه الزامات

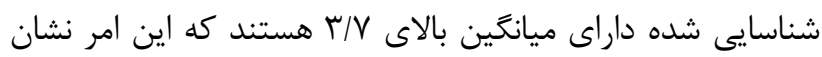
دهنده اهميت بالاى هر كدام از اين عناصر دادهاى است.

كاربرد الزامات و راهبردهاى بيشنهاد شده در مطالعه حاضر

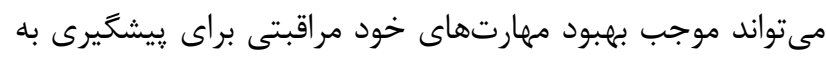

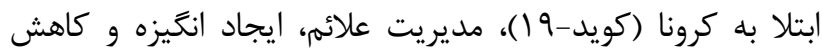
استرس، افزايش سطح بهداشت فردى و ارتباط با ارائه دهندكان مراقب سلامت كردد.

\section{بيشنهادها}

ييشنهاد مىشود يزوهشهاى آينده به توسعه و ارزيابى

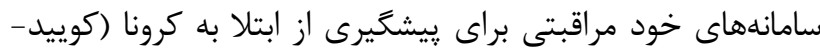

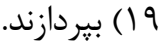

\section{سياسگزارى}

بدين وسيله از كليه استادان و كاركنان شاغل در مركز تحقيقات ويروس شناسى بيمارستان مسيح دانشورى كه در انجام

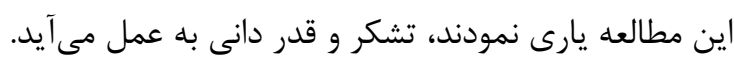

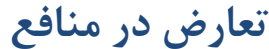

اين مقاله يزوهشى مستقل است كه بدون حمايت مالى سازمانى انجام شده است. در انجام مطالعأ حاضر، نويسندكان هيج كونه تضاد منافعى نداشتهاند.
يزووهش نعمت الهى و همكاران مطابقت داشت. آنها نتيجه گيرى

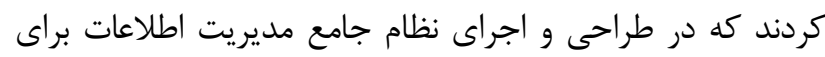

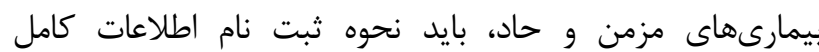

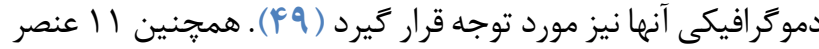
دادهاى طبق نظر متخصصان بيمارىهاى عفونى براى حوزه بالينى

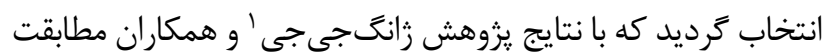
داشت. آنها نتيجه كيرى كردند كه شايعترين علائم بالينى بيماران

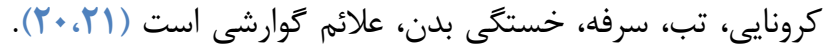

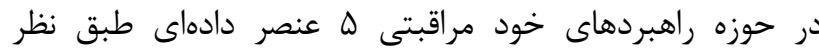

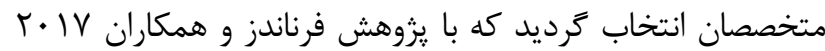

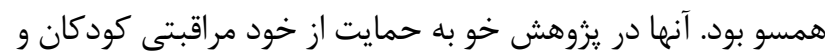

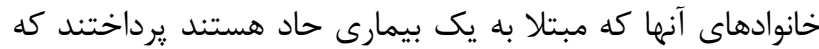

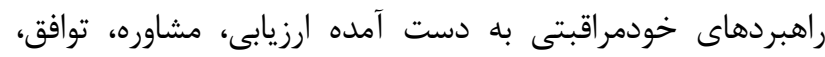
مراقبت و همراهى بود (•ه). در تحقيقات مشابه ضمن تاكيد بر برد راهبردهاى خود مراقبتى براى شرايط حاد و مزمن به اين مهمم اشاره شده كه با بهبود سبك زندگى در قالب برنامههاى خود مراقبتى، نه

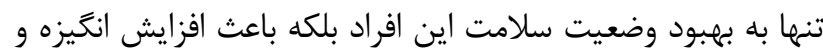
توانايى آنان در مشاركت طرح هاى درمانى نيز كمك مي كند. حوزه ويزگى هاى فنى با / 1 اعنصر دادهاى انتخاب شده توسط متخصصان بيمارىهاى عفونى كامل شد هنرى و موورى در يزوهش مشابلهى

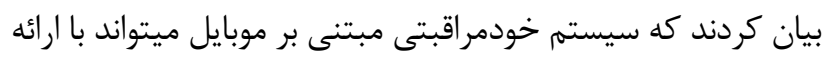

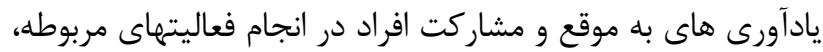
در اين زمينه بسيار كمك كننده باشد (•ه).

\section{نتيجلَكيرى}

يزوهش يِيش روى با هدف شناسايى الزامات سامانه خود مراقبتى مبتنى بر موبايل براى يِيشگيرى از ابتلا به ويرووس كرونا

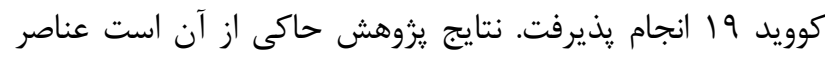

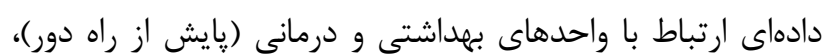

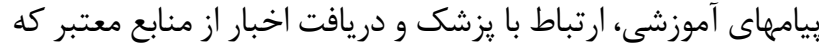

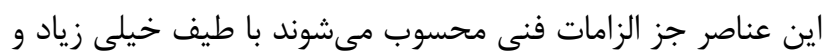

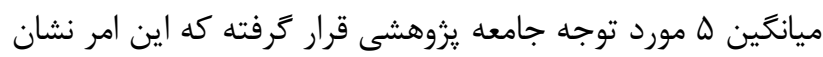

\section{Referance}


1. Fawcett JJNsq. The Nurse Theorists: 21st-Century Updates-Dorothea E. Orem. 2001;14(1):34-8. [DOI:10.1177/08943180122108021] [PMID]

2. Dean KJSS, Psychology MPAM, Sociology M. Selfcare responses to illness: a selected review. 1981;15(5):673-87.

[DOI:10.1016/02717123(81)90091-2]

3. DORAN DJLJ, International BP. Functional Status. Nursing-sensitive Outcomes: state of the science. 2003.

4. Valdez RS, Holden RJJEiD. Health care human factors/ergonomics fieldwork in home and community settings. 2016;24(4):4-9. [DOI:10.1177/1064804615622111] [PMID] [PMCID]

5. Srinivas P, Cornet V, Holden RJJJoHCI. Human factors analysis, design, and evaluation of Engage, a consumer health IT application for geriatric heart failure $\quad$ self-care. 2017;33(4):298-312. [DOI:10.1080/10447318.2016.1265784] [PMID] [PMCID]

6. Riegel B, Dickson VV, Faulkner KMJJoCN. The situation-specific theory of heart failure self-care: revised and updated. 2016;31(3):226-35. [DOI:10.1097/JCN.0000000000000244] [PMID]

7. Novak LL, Unertl KM, Holden RJJSiht, informatics. Realizing the potential of patient engagement: designing IT to support health in everyday life. 2016;222:237.

8. Holden RJ, Kulanthaivel A, Purkayastha S, Goggins KM, Kripalani SJIjomi. Know thy eHealth user: Development of biopsychosocial personas from a study of older adults with heart failure. 2017;108:15867. [DOI:10.1016/j.ijmedinf.2017.10.006] [PMID] [PMCID]

9. Zachary WW, Michlig G, Kaplan A, Nguyen N-T, Quinn CC, Surkan PJ, editors. Participatory design of a social networking app to support Type II Diabetes self-management in low-income minority communities. Proceedings of the International Symposium on Human Factors and Ergonomics in Health Care; 2017: SAGE Publications Sage CA: Los Angeles, CA. [DOI:10.1177/2327857917061010] [PMID] [PMCID]

10. Cage K, Santos L, Scott C, Vaughn-Cooke M, editors. Personal health record design preferences for minority diabetic patients. Proceedings of the Human Factors and Ergonomics Society Annual Meeting; 2014: SAGE Publications Sage CA: Los Angeles, CA. [DOI:10.1177/1541931214581131]

11. Kwok J, Burns CM, editors. Usability evaluation of a mobile ecological interface design application for diabetes management. Proceedings of the Human Factors and Ergonomics Society Annual Meeting;
2005: SAGE Publications Sage CA: Los Angeles, CA. [DOI:10.1177/154193120504901109]

12. Beer JM, McBride SE, Mitzner TL, Rogers WAJAe. Understanding challenges in the front lines of home health care: a human-systems approach. 2014;45(6):1687-99.

[DOI:10.1016/j.apergo.2014.05.019] [PMCID]

13. Woods SP, Iudicello JE, Morgan EE, Cameron MV, Doyle KL, Smith TV, et al. Health-related everyday functioning in the internet age: HIV-associated neurocognitive disorders disrupt online pharmacy and health chart navigation skills. 2016;31(2):176-85. [DOI:10.1093/arclin/acv090] [PMID] [PMCID]

14. Dodson S, Klassen KM, McDonald K, Millard T, Osborne RH, Battersby MW, et al. HealthMap: a cluster randomised trial of interactive health plans and self-management support to prevent coronary heart disease in people with HIV. 2016;16(1):114. [DOI:10.1186/s12879-016-1422-5] [PMID] [PMCID]

15. Niakan S, Mehraeen E, Noori T, Gozali E, editors Web and Mobile Based HIV Prevention and Intervention Programs Pros and Cons-A Review. eHealth; 2017.

16. Ramanathan N, Swendeman D, Comulada WS, Estrin D, Rotheram-Borus MJJIjomi. Identifying preferences for mobile health applications for self-monitoring and self-management: focus group findings from HIVpositive persons and young mothers. 2013;82(4):e38e46. [DOI:10.1016/j.ijmedinf.2012.05.009] [PMID] [PMCID]

17. Mehraeen E, Safdari R, SeyedAlinaghi S, Mohammadzadeh N, Mohraz MJEp. Common elements and features of a mobile-based selfmanagement system for people living with HIV. 2018;10(4):6655. [DOI:10.19082/6655] [PMID] [PMCID]

18. Copeland TJA, medicine. Self-managing HIV/AIDS: cultural competence and health among women in Nairobi, Kenya. 2018;25(2):176-90. [DOI:10.1080/13648470.2017.1285002] [PMID]

19. Richardson P, Griffin I, Tucker C, Smith D, Oechsle $\mathrm{O}$, Phelan A, et al. Baricitinib as potential treatment for 2019-nCoV acute respiratory disease. 2020;395(10223):e30-e1. [DOI:10.1016/S01406736(20)30304-4]

20. Zhang Jj, Dong X, Cao YY, Yuan Yd, Yang Yb, Yan Yq, et al. Clinical characteristics of 140 patients infected by SARS-CoV-2 in Wuhan, China. 2020. [DOI:10.1111/all.14238] [PMID]

21. Zhu N, Zhang D, Wang W, Li X, Yang B, Song J, et al. A novel coronavirus from patients with pneumonia in China, 2019. 2020. 
22. Betsch C, Wieler L, Bosnjak M, Ramharter M, Stollorz V, Omer S, et al. Germany COVID-19 Snapshot MOnitoring (COSMO Germany): Monitoring knowledge, risk perceptions, preventive behaviours, and public trust in the current coronavirus outbreak in Germany. 2020.

23. Huang C, Wang Y, Li X, Ren L, Zhao J, Hu Y, et al. Clinical features of patients infected with 2019 novel coronavirus in Wuhan, China. 2020;395(10223):497506. [DOI:10.1016/S0140-6736(20)30183-5]

24. 24. Cao J, Hu X, Cheng W, Yu L, Tu W-J, Liu QJICM. Clinical features and short-term outcomes of 18 patients with corona virus disease 2019 in intensive care unit. 2020:1-3. [DOI:10.1093/cid/ciaa243] [PMID] [PMCID]

25. Guo Y-R, Cao Q-D, Hong Z-S, Tan Y-Y, Chen S-D, Jin H-J, et al. The origin, transmission and clinical therapies on coronavirus disease 2019 (COVID-19) outbreak-an update on the status. 2020;7(1):1-10. [DOI:10.1186/s40779-020-00240-0]

[PMID] [PMCID]

26. Lipsitch M, Swerdlow DL, Finelli LJNEJoM. Defining the epidemiology of Covid-19-studies needed. 2020. [DOI:10.1056/NEJMp2002125] [PMID]

27. Wang D, Hu B, Hu C, Zhu F, Liu X, Zhang J, et al. Clinical characteristics of 138 hospitalized patients with 2019 novel coronavirus-infected pneumonia in Wuhan, China. 2020. [DOI:10.1001/jama.2020.1585] [PMID] [PMCID]

28. Wang C, Pan R, Wan X, Tan Y, Xu L, Ho CS, et al. Immediate psychological responses and associated factors during the initial stage of the 2019 coronavirus disease (COVID-19) epidemic among the general population in china. 2020;17(5):1729. [DOI:10.3390/ijerph17051729] [PMID] [PMCID]

29. Pan F, Ye T, Sun P, Gui S, Liang B, Li L, et al. Time course of lung changes on chest CT during recovery from 2019 novel coronavirus (COVID-19) pneumonia. 2020:200370. [DOI:10.1148/radiol.2020200370] [PMID] [PMCID]

30. Song Y, Jiang J, Yang D, Bai CJCe. Prospect and application of Internet of Things technology for prevention of 2020. [DOI:10.1016/j.ceh.2020.02.001] [PMCID]

31. Chen N, Zhou M, Dong X, Qu J, Gong F, Han Y, et al. Epidemiological and clinical characteristics of 99 cases of 2019 novel coronavirus pneumonia in Wuhan, China: a descriptive study. 2020;395(10223):507-13 . [DOI:10.1016/S0140-6736(20)30211-7]

32. Xiao H, Zhang Y, Kong D, Li S, Yang NJMSMIMJoE, Research C. The Effects of Social Support on Sleep Quality of Medical Staff Treating Patients with Coronavirus Disease 2019 (COVID-19) in January and
February 2020 in China. 2020;26:e923549-1. [DOI:10.12659/MSM.923921]

33. Ringbæk T, Green A, Laursen LC, Frausing E, Brøndum E, Ulrik CSJIjocopd. Effect of tele health care on exacerbations and hospital admissions in patients with chronic obstructive pulmonary disease: a randomized clinical trial. 2015;10:1801. [DOI:10.2147/COPD.S85596] [PMID] [PMCID]

34. Peeri NC, Shrestha N, Rahman MS, Zaki R, Tan Z, Bibi S, et al. The SARS, MERS and novel coronavirus (COVID-19) epidemics, the newest and biggest global health threats: what lessons have we learned? 2020. [DOI:10.1093/ije/dyaa033] [PMID] [PMCID]

35. Smith AC, Thomas E, Snoswell CL, Haydon H, Mehrotra A, Clemensen J, et al. Telehealth for global emergencies: Implications for coronavirus disease 2019 (COVID-19). 2020:1357633X20916567. [DOI:10.1177/1357633X20916567] [PMCID]

36. Mak WW, Law RW, Woo J, Cheung FM, Lee DJP, Health. Social support and psychological adjustment to SARS: The mediating role of self-care self-efficacy. 2009;24(2):161-74. [DOI:10.1080/08870440701447649] [PMID]

37. Hollander JE, Carr BGJNEJoM. Virtually perfect? Telemedicine for covid-19. 2020. [DOI:10.1056/NEJMp2003539] [PMID]

38. Lunn P, Belton C, Lavin C, McGowan F, Timmons S, Robertson D. Using behavioural science to help fight the coronavirus. 2020. [DOI:10.30636/jbpa.31.147]

39. Kirk GD, Himelhoch SS, Westergaard RP, Beckwith CGJAr, treatment. Using mobile health technology to improve HIV care for persons living with HIV and substance abuse. 2013;2013. [DOI:10.1155/2013/194613] [PMID] [PMCID]

40. Wade TR, ACKERMAN BAJDS. The many faces of keratoacanthomas. 1978;4(7):498-501. [DOI:10.1111/j.1524-4725.1978.tb00483.x] [PMID]

41. Belzer ME, Naar-King S, Olson J, Sarr M, Thornton S, Kahana SY, et al. The use of cell phone support for non-adherent HIV-infected youth and young adults: an initial randomized and controlled intervention trial. 2014;18(4):686-96. [DOI:10.1007/s10461-013-06613] [PMID] [PMCID]

42. L'Engle KL, Green K, Succop SM, Laar A, Wambugu SJJrp. Scaled-up mobile phone intervention for HIV care and treatment: protocol for a facility randomized controlled trial. 2015;4(1):e11. [DOI:10.2196/resprot.3659] [PMID] [PMCID]

43. Stoller EP, Webster NJ, Blixen CE, McCormick RA, Perzynski AT, Kanuch SW, et al. Lay management of chronic disease: a qualitative study of living with hepatitis C infection. 2009;33(4):376-90. [DOI:10.5993/AJHB.33.4.4] [PMID] [PMCID] 
44. Negin J, Nyirenda M, Seeley J, Mutevedzi PJJoc-cg. Inequality in health status among older adults in Africa: the surprising impact of anti-retroviral treatment. 2013;28(4):491-3. [DOI:10.1007/s10823-013-9215-4] [PMID]

45. Donovan JL, Blake DR. Qualitative study of interpretation of reassurance among patients attending rheumatology clinics: "just a touch of arthritis, doctor?". BMJ (Clinical research ed). 2000;320(7234):541-4. [DOI:10.1136/bmj.320.7234.541] [PMID] [PMCID]

46. Nematollahi M, Khalesi N, Moghadasi HJP. The comparative investigation of HIV/AIDS surveillances in the selected countries. 2012;11(4):425-33.

47. Fernandes LTB, Nóbrega VMd, Silva MEdA, Machado AN, Collet NJRbde. Supported self-care for children and adolescents with chronic disease and their families. 2017;70(6):1318-29. [DOI:10.1590/00347167-2016-0553] [PMID]

48. Bärnighausen T, Chaiyachati K, Chimbindi N, Peoples A, Haberer J, Newell M-LJTLid. Interventions to increase antiretroviral adherence in sub-Saharan Africa: a systematic review of evaluation studies. 2011;11(12):942-51. [DOI:10.1016/S14733099(11)70181-5

49. Rosen S, Fox MP, Gill CJJPM. Patient retention in antiretroviral therapy programs in sub-Saharan Africa: a systematic review. 2007;4(10):e298. [DOI:10.1371/journal.pmed.0040298] [PMID] [PMCID]

50. Henry BL, Moore DJJJotAoNiAC. Preliminary findings describing participant experience with iSTEP, an mHealth intervention to increase physical activity and improve neurocognitive function in people living with HIV. 2016;27(4):495-511. [DOI:10.1016/j.jana.2016.01.001] [PMID] [PMCID] 